\title{
XIV. On the British Species of the Genus Gelechia of Zeller. By J. W. Douglas, Esq. (Continued from page 68.)
}

[Read 6th Jan., 1851.]

Sp. 81. Fraternella, mihi.

Alæ anticæ latæ, obtusæ, griseo-fuscæ, puncto humerali, maculâ magnâ nigrâ ante medium, fasciâ posticâ interruptâ flavescenti internè nigro irregularitèr marginatâ; apice medio nigro, ciliis griseis. Alæ posticæ griseæ.

Expansion of wings $5 \frac{1}{2}$ lines.

Head fuscous ; face pale ; palpi griseous, terminal joint black ; antennæ annulated black and white. Anterior wings greyishfuscous, broad in proportion to their length, and obtuse; a small humeral spot followed by a large black, somewhat linear blotch, reaching obliquely to the groove; beyond the middle the colour becomes nearly black on the costa and inferior margin, a somewhat rufous mark being in the centre, extending across the adjacent rather broad yellowish fascia; apex black, broadly bordered with the lighter colour of the wings, which extends through the cilia. Posterior wings griseous.

Taken by Mr. Stainton at Lewisham, in August, out of mixed hedges, in company with $G$. contigua.

From this species it may be distinguished by the absence of the continuous black costal blotch, and by wanting the rufous tinge on the inner margin of the anterior wings, which in fraternella are also shorter and more obtuse.

Differs from $G$. vicinella in the greater breadth and obtuseness of the anterior wings, in the inferior margin not being pale, and the posterior fascia being narrower.

Differs from $G$. maculiferella, in the larger size, more obtuse anterior wings, on which the large blotch is not angulated, the generally darker colour, and other minor characters.

It is perhaps more like $G$. peliella than any other; but may at once be known from that species by its smaller size, and having the end of the posterior fascia on the inner margin nearer the base of the wing than that on the anterior edge; whereas in peliella, the spots answering to the posterior fascia are reversely placed. 


\section{Sp. 82. Vicinella, mibi.}

Alæ anticæ fuscæ, puncto basali, maculâ latâ costali ante, alterâque minori discoidali pone medium, atris, fasciâ posticâ latâ vix interruptâ albidâ. Alæ posticæ griseæ.

Expansion of wings 6 lines.

Head griseous; palpi griseous, terminal joint black; antennæ faintly annulated black and white. Anterior wings greyish fuscous, interior margin whitish, a basal spot, a large blotch reaching obliquely from the costa to the groove, before the middle, and a smaller central one beyond the middle, black; a broad whitish posterior fascia barely interrupted in the centre; apex fuscous, with a black spot in the centre; cilia griseous. Posterior wings and cilia griseous.

Two specimens in the cabinet of Mr. Stainton, taken by Mr. Jobson near Belfast.

Resembles $G$. contigua, but differs in the large black blotch of the anterior wings not being continued along the costa, in the presence of a second blotch beyond the middle, in the inferior margin being pale, not rufous, and in the breadth of the hinder fascia.

Differs from $G$. fraternella in the anterior wings being longer and more acute, in the first blotch being larger, in the posterior fascia being broader, and in having the inferior margin pale.

$$
\begin{aligned}
& \text { Sp. 83. Maculiferella, } \\
& \text { * G. maculiferella, (F. v. R.), Mann. (MSS.) } \\
& \text { Re. proxima, Haw. (non Ti. proximella, H.) }
\end{aligned}
$$

“Alæ anticæ griseæ, maculâ magnâ ante medium atrâ angulatâ, vel sinuatâ fasciæformi, à costâ fere ad marginem tenuirorem; et pone hanc nebulis aliquot atris."-Haworth.

Expansion of wings 5 lines.

Head fuscous, face pale; antennæ annulated black and white; palpi griseous, terminal joint black. Anterior wings griseous or greyish-fuscous, paler at the base, near which is a small black spot; before the middle is a large, somewhat angulated blotch, the point of which reaches nearly to the inner margin; beyond the middle are two or three irregular black marks, and then a pale fascia; apex griseous with a black angular spot in the centre. Posterior wings and cilia griseous. 
Found by Mr. Bentley on the trunks of poplars.

Haworth's specimen is in the collection of the Entomological Society.

Differs from $G$. junctella in the greater paleness of the base, in the angular form and larger size of the blotch before the middle, in the absence of the rufous patch beyond, in the slighter whitish fascia, and the broader margin of griseous to the apex.

Differs from $G$. marmorea in being less, in the paler base and darker inner margin, in the form and distinctness of the blotch before the middle, and in the dark colour not being continued along the costa.

Haworth places it next to contigua and sequax, and says, "Hæc et duæ præcedentes forte mera varietates sunt, sed characteribus valde diversis." I do not see so much resemblance to sequax; but it is more like contigua, from which it differs in being smaller, in the costal blotch being very different in form, not touching the costa in its whole length, but only at its origin; in the whitish hinder fascia not being expanded on the costa, and in the absence of a rufous tinge on the inner margin.

\section{Sp. 84. Junctella, mihi.}

Alæ anticæ griseo-albidæ, puncto humerali, fasciâ latâ abbreviatâ obliquâ ante, alterâ punctorum formâ pone medium, atris ; tertiâque rectâ albidâ: apice atro. Alæ posticæ griseæ.

Expansion of wings $4 \frac{1}{2}-5$ lines.

Head shining bronze; palpi griseous, terminal joint black ; antennæ annulated black and white. Anterior wings greyish-white, a black humeral spot, a thick black sub-linear fascia or blotch reaching obliquely to the groove, before the middle; beyond the centre an oblique row of black dots disposed as a slender fascia, joined to which and reaching to a whitish fascia which stretches quite across the wing, is an angular rufous blotch; apex black, bordered with griseous; cilia griseous. Posterior wings and cilia griseous.

Found by Mr. Bouchard in August on trunks of oaks, in company with $G$. Hübneri, to which species this bears considerable resemblance in the disposition of the markings; but the general darker colour and the nearly straight whitish fascia are so different that I cannot consider it identical therewith. There is also great resemblance to the preceding $G$. maculiferella, from which however it may be known at first sight by the first fascia or blotch 
being linear, not angulated; the inner margin also is paler. From G. marmorea it differs in being slightly less, of a greyer colour, paler on the inner margin; the first fascia well defined, not merged in the ground colour; the whitish fascia being also well defined, and the apex of the wing darker.

\section{Sp. 85. Marmorea.}

Re. marmorea, Haw.

An. marmorea, St.

An. guttifera, Wood, 1216.

*G. Manniella (F. v. R.), Z.

Expansion of wings 5 lines.

Head rufous; palpi, second joint griseous above, black beneath, terminal joint black. Thorax rufous. Anterior wings rufous, sometimes nearly black, with a darker, thick streak extending from the costa before the middle, and a blackish spot on the disk beyond, adjoining which is a slender yellowish fascia; the inner margin is pale rufous or ochreous to beyond the middle, extending upwards to the centre of the wing in the form of a double arch. Posterior wings griseous.

Found abundantly on the sand-hills at New Brighton, Cheshire, at Chesil Bank near Weymouth, and Dawlish Warren. There is not a tree of any kind near these places, and therefore I am inclined to think that, although it is taken on trunks of firs at Glogau and Frankfort, it only goes there for shelter. Neither can I concur in the opinion that maculiferella and junctella are only varieties; for among hundreds of specimens of marmorea, many of them most extraordinary variations, I never saw one that could be referred to either of those species; and all three are found by us in different localities and under different circumstances, as I have indicated under each.

Differs from $G$. junctella in being larger ; anterior wings having the colour of the superior and inferior margins more distinct and meeting abruptly in the centre, the hinder fascia narrower and more obliquely placed; apex paler.

Differs from $G$. maculiferella in being larger, anterior wings browner, wanting the pale base and the large angulated blotch; in the entire costa being dark, and in having a well-defined, light inner margin.

These last five species, possessing characters very much in common, form a group not easily divisible, and difficult to iden- 
tify if one be taken alone; but when seen together and in quantity they seem to me, independently of the variation of time of appearance and the circumstances pertaining to different localities, to be naturally divisible into distinct species.

\section{Sp. 86. Basaltinella.}

G. Basaltinella, Z.

Re. domestica, var. $\beta$, Haw.

Head and thorax concolorous with the anterior wings; palpi griseous, terminal joint black; antennæ black, faintly annulated with white. Anterior wings ashy-fuscous, with an apical yellowish fascia, a spot at the base of the costa, and four black ones placed as in G. domestica, the two central ones being, as in that species, frequently confluent. Posterior wings griseous.

Several specimens taken by Mr. Bedell, last June, out of old thatch at Addington.

Under the head of G. domestica (vol. v. p. 198) I have without doubt given $G$. Basaltinella as a synonym, but an examination of recent specimens has led me to think with Herr Zeller that it is distinct. The whole insect is very much darker than domestica, although the size and markings are the same; it agrees exactly with Haworth's var. $\beta$, which is preserved in the collection of the Entomological Society, and of which he observes, "Forte propria species."

\section{Sp. 87. Boreella, mihi.}

Alæ anticæ latæ, obtusæ, griseo-fuscæ, punctis, tribus disco, atris, lineâ brevi medio, fasciâque posticâ acutè bi-angulatâ, albidis. Alæ posticæ griseæ.

Expansion of wings $6 \frac{1}{2}$ lines.

Head and thorax concolorous with the anterior wings; palpi of the same hue, terminal joint black; antennæ black. Anterior wings broad, obtuse, grey-fuscous; in the groove a black spot, another above and beyond, but both before the middle; a third beyond the middle in a line with the second, from which it is divided by a linear whitish streak; a posterior, narrow whitish fascia, acutely bi-angulated in the centre, beyond this the apex is darker than the rest of the wing, bordered on the hinder margin with a black line, and on the costa with black dots; cilia griseous ; Posterior wings griseous.

A single specimen, taken by Mr. Stainton, 14th July, 1850, on boggy ground on the shores of the Holy Loch, Argyleshire. 


\section{Sp. 88. Paupella.}

G. paupella, Z. (Isis, 1847, p. 858).

"Alis anterioribus albidis, lineis longitudinalibus fusco-marginatis, striga marginis postici latiore utrinque attenuata. Mas."

" Most closely allied to G. inopella, of which it almost appears to be merely an enlarged, sharper and yellower form of the South; however, its palpi are proportionably longer and the tongue is shorter. Head and thorax white; antennæ whitish, towards the apex more distinctly dark grey annulated; tongue (accidentally unrolled) only as long as the labial palpi ; labial palpi recurved, three times as long as the head, thin, somewhat compressed, whitish, the last joint a little thinner than the second, shorter, pointed. Legs white, the first two pairs on the anterior side brown, the ends of the joints white; all the tibiæ covered with long hairs. The pale grey abdomen has a long white anal tuft. Anterior wings white; from the base a posteriorly pointed yellowish streak goes close to the costa, ceasing before the middle (in inopella the white costa is broader); under the middle of the wing is another longer, attenuated streak reaching further than this, three shorter ones on the disk, and a sixth on the hinder margin, broad, attenuated at both ends, but not touching the opposite margins ; behind it the cilia are white and round, their apices are marked with two rows of brown scales running nearly parallel to the hinder margin, between them the ground colour is yellowish; the costa has at the base of the cilia five remote, brown spots; all the streaks are encompassed with scattered brown scales on their margins. Posterior wings very narrow, somewhat shining, pale grey, with rather long apex, before which the hinder margin is deeply and bluntly emarginated; cilia very long, yellowish-grey. Under side shining, pale grey, on the anterior wings darker; all the wings are paler on the disk.

"One male I took near Syracuse in a flowery path through the moist meadow between the Anapo and the columns of $\mathrm{Ju}$ piter's Temple, on the 19th of May."-Z. loc. cit.

I have one specimen which I took flying at Folkestone in July, 1850 , in a somewhat wasted condition, having only traces of the streaks, but which, nevertheless, Herr Zeller pronounces without doubt to be paupella, adding the remark, " thus England has another species in common with Sicily." 
Sp. 89. Cerealella.

Alucita cerealella, Encycl. Méthod., Entom. tom. i. p. 121, No. 15.

Butalis cerealella, D. Supp. p. 444, pl. 85, fig. 3.

Ecophora granella, Latr.

*G. Pyrophagella, Kollar in lit., Z. in lit.

Expansion of wings $6 \frac{1}{2}$ lines.

Head pale ochreous ; palpi concolorous, with the extreme tip fuscous; antennæ luteous. Anterior wings narrow, acute, deep ochreous or luteous, with brownish atoms at the apex and on the cilia. Posterior wings narrow, with long, acute apex, greyish, with a luteous tinge, especially on the cilia. Posterior legs and tarsi pale luteous.

I have one specimen taken by myself many years since, but I have no record of the locality.

In France this Tinea has proved very destructive to corn; wheat, barley and rye being indiscriminately attacked by it. Duponchel (loc. cit.), quoting from the Memoirs of Reaumur, Duhamel-Dumonceau and Tillet on its natural history, inform us that the female lays her eggs on the grains of these three kinds of corn before they are ripe. Six or seven days afterwards the caterpillars appear, being hardly as thick as a hair, and each one attacks a grain, introducing itself into it by a hole so small that it is not visible to the naked eye. Here it lives, taking care not to break the husk of the grain, so that the affected seeds cannot be distinguished from the sound except by putting into water, when the former swim and the latter sink. When arrived at perfection, the caterpillar, still within the grain that has afforded it food, spins a cocoon of white silk, having first taken the precaution to gnaw one of the ends in such a manner as to form a kind of operculum, which readily yields to the efforts of the moth to escape from its prison. This escape usually takes place after the corn is thrashed and laid up in granaries, but specimens sometimes appear before this is accomplished.

Several methods for preventing or diminishing the ravages of this Tinea have been suggested, the principal being exposure in machines to heat or carbonic gas. In the former it was found that corn would germinate after exposure to a temperature of 70 degrees, Reaumur, and that a higher temperature, 76 to 96 degrees, for a short period, was less effectual in accomplishing the destruction of the larvæ than a lower one, 45 to 50 degrees, continued for a longer time. In the other method the corn has been found not to be deteriorated for making bread, nor to have lost the power of germinating. 
I am not aware that this insect, which appears to be a great pest in granaries in France, has been observed in similar places in this country, though from the ignorance of insects generally among those most immediately affected by their ravages, it may exist in plenty without having been distinguished from other moths whose larvæ feed on grain. My own is the only British specimen I have seen.

\section{Sp. 90. Nigritella.}

$$
\text { G. nigritella, Z. (Isis, 1847, p. 857.) }
$$

"Alis anterioribus fusco-nigris, guttalis duabus posticis oppositis pallidis obsoletis; posteriorum apice valdè producto ; palporum articulo terminali longo; antennis fuscis. Mas."

"Very near to G. Coronillella, and from it certainly distinguished by the narrow anterior wings and unicolorous brown (not pale-annulated) antennæ. A little larger than an ordinary male Coronillella; anterior wings narrow and more pointed, darker spots on the disk are not visible, except one with difficulty perceptible on the fold at the beginning of the last third; the two pale opposite spots are very small and faint, especially the lower one, which stands inwards, instead of, as in Coronillella, perpendicularly under the other. The pale, grey posterior wings have in the male sex a stronger, more prolonged apex, the emargination below it is much blunter, and the projecting part of the hinder margin, before the emargination, is not so convex. The entire underside is rather paler than in Coronillella. The antennæ in this latter are distinctly annulated brown and white, and have on the under side of the basal joint a white long streak; in nigritella they are quite unicolorous brown, on the under side of the basal joint whitish; in the palpi of both species the terminal joint is the longest, but in Coronillella it has on the outer and inner side a white long line, in nigritella it glitters on the entire inner side and also on the back, whitish, but nowise in a fine long line. Hinder tibiæ and tarsi are in nigritella more slender."

"A single male, taken 3rd May near Messina, high on the southern slope of a mountain, among wild lupins." Z. loc. cit.

A single specimen captured several years since, but of whose capture I have no record, has been submitted to Herr Zeller, who says that he has no hesitation in pronouncing it to be nigritella, although it differs from his specimen in having the terminal joint of the palpi shorter, the white on the back of the palpi in a more distinct line, and the traces of two opposite spots on the wings less evident. 


\section{$2 \mathrm{BHL}$ Biodiversity Heritage Library}

Douglas, J W. 1851. "XIV. On the British Species of the Genus Gelechia of Zeller." Transactions of the Entomological Society of London 6, 101-108. https://doi.org/10.1111/j.1365-2311.1851.tb02489.x.

View This Item Online: https://www.biodiversitylibrary.org/item/55127

DOI: https://doi.org/10.1111/j.1365-2311.1851.tb02489.x

Permalink: https://www.biodiversitylibrary.org/partpdf/56848

\section{Holding Institution}

Smithsonian Libraries

\section{Sponsored by}

Smithsonian

\section{Copyright \& Reuse}

Copyright Status: Public domain. The BHL considers that this work is no longer under copyright protection.

This document was created from content at the Biodiversity Heritage Library, the world's largest open access digital library for biodiversity literature and archives. Visit BHL at https://www.biodiversitylibrary.org. 